\title{
A Report and Request toward Building a Canine Burial Corpus
}

\author{
Duncan P. McKinnon \\ University of Central Arkansas
}

Follow this and additional works at: https://scholarworks.sfasu.edu/ita

Part of the American Material Culture Commons, Archaeological Anthropology Commons, Environmental Studies Commons, Other American Studies Commons, Other Arts and Humanities Commons, Other History of Art, Architecture, and Archaeology Commons, and the United States History Commons

Tell us how this article helped you.

This Article is brought to you for free and open access by the Center for Regional Heritage Research at SFA ScholarWorks. It has been accepted for inclusion in Index of Texas Archaeology: Open Access Gray Literature from the Lone Star State by an authorized editor of SFA ScholarWorks. For more information, please contact cdsscholarworks@sfasu.edu. 


\section{A Report and Request toward Building a Canine Burial Corpus}

Creative Commons License

(c) () () (9)

This work is licensed under a Creative Commons Attribution-NonCommercial 4.0 International License 


\title{
Current Research:
}

\section{A Report and Request toward Building a Canine Burial Corpus}

\author{
Duncan P. McKinnon \\ University of Central Arkansas
}

\begin{abstract}
Both the affectionate and mutually adaptive relationships that contemporary humans share with the $\operatorname{dog}$ (Canis familiaris) are the result of a long history of domestication. Because of this long partnership, an analysis of dog burials can shed light on certain integrated components associated with mortuary practices, symbolic expression, and oral traditions in humans. There is an enormous amount of archeological and ethnological literature describing the role of the domesticated dog around the world (Walker 2000). These sources describe the variable roles of dogs as human partners, friends, companions in hunting and herding, as pack animals, as guard, fighting, and war dogs, as active participants in ritual, and as meat for consumption in lean times or reserved as offerings in ceremonial feasting.

There is little question that the domesticated dog was an important partner and treated with a high degree of adulation and reverence among the Caddo. For example, dogs are recorded as participating in precautionary rituals associated with the Caddo Green Corn ceremony where a series of rituals and offerings are undertaken prior to the consumption of the green corn. If green corn were eaten by a human before the rituals, the violator would "be infallibly bitten by a snake" (Swanton 1942:225). To protect dogs from such an outcome, it is noted that when corn is harvested "[the Hasinai] tie their [dogs] fore-feet to their snouts, which prevents their eating fresh corn, of which they are exceedingly fond" (Swanton 1942:225).

Building upon the work of Todd (2013), I am working toward synthesizing patterns of burial, symbolic referents, and ethnographic accounts of dogs in the Caddo area and begin a comparison of symbolism and ethnography with neighboring groups. The current corpus has 65 dog burials with a minimum number of 79 dogs from 34 sites (Figure 1). Consideration of disposed dogs as deliberate burials, instead of scattered food refuse, is based on the following developed criteria:
\end{abstract}

1. Remains were found in an articulated position and buried in a defined pit. At the Roitsch site, Perttula (2008:344) describes an "adult-sized dog [that] had been buried on its side in a ca. $80 \mathrm{~cm}$ diameter pit, with its head at the eastern end of the pit, and the front and back legs were partially flexed."

2. If the remains were found in an articulated or mostly articulated position without a defined pit, such as in a midden. At the Steck site a dog burial was found "lying on the left side with the head to the north, excavated from the midden" (Butler and Perttula 1981:123).

3. If the remains were associated with more than one dog, such as a group of skulls which might suggest a dedicated space for dog burial or disposal. At the Winterbauer site, "nine canid skulls, probably marking the deliberate burial.... of dogs [were found] in the midden deposits, in the southern part of the midden mound" (Perttula 2015:24).

4. If the remains were located in a disturbed area containing an abundance of dog bone fragments suggesting a former burial. At the Mahaffey site, Perino and Bennett (1978:12) describe a potential burial of "bones [that] had been badly destroyed by rodents. It contained a few scattered bones plus a skull and jaw sections."

Based on archeological and ethnohistorical data collected thus far, it is clear there existed a special relationship with dogs. This is likely because they were considered members of the community and were also certainly valuable as hunters. There are several cases where dogs have been buried within prepared pits and with burial goods. Such special treatment suggests a similar concern as shown with human burials where burial goods were placed as provisions for the next world (see also Schwartz 2000).

As I move forward with this long-term project, I am reaching out to those who are aware of dog burials (and citations) to build and expand the corpus. I am interested in Caddo area dog burials and those in neighboring groups, such as the Quapaw, Natchez, Wichita, and Pawnee. 


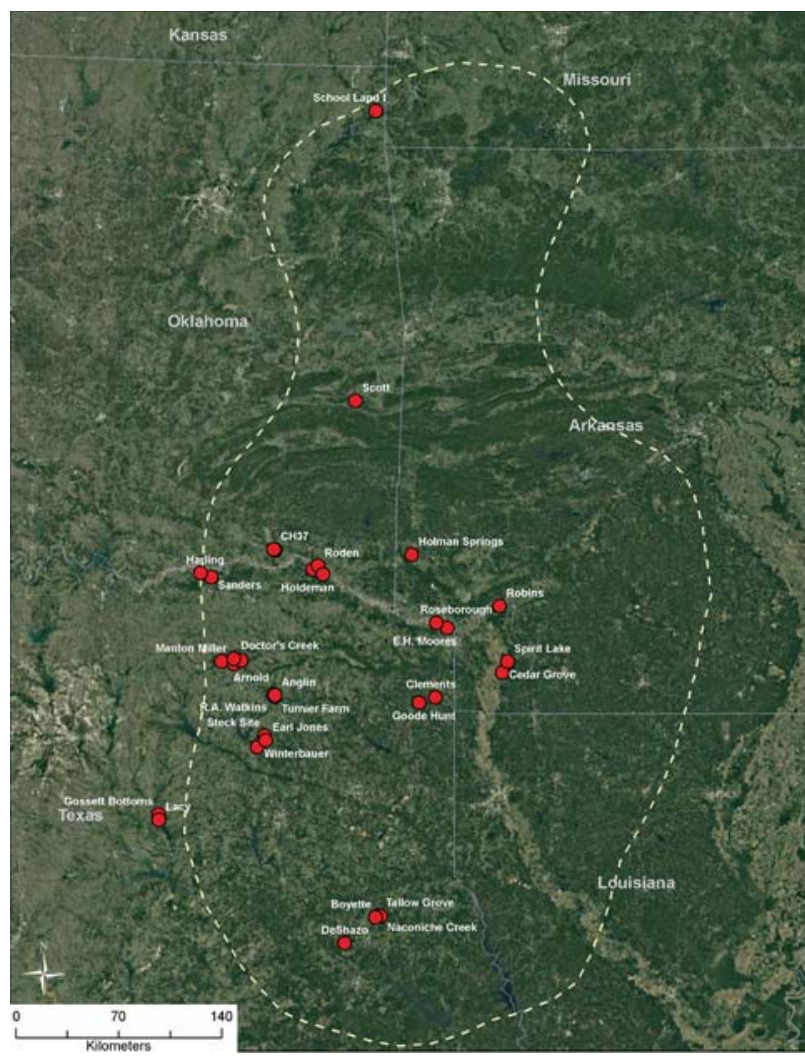

Figure 1. Distribution of the current corpus of dog burials in the Caddo area.

\section{References Cited}

Butler, Barbara H., and Timothy K. Perttula

1981 Subsistence Analysis. In Prehistoric Settlement Patterns at Lake Fork Reservoir, by James E. Bruseth and Timothy K. Perttula, pp. 117125. Texas Antiquities Permit Series No. 2. Archaeology Research Program, Southern Methodist University, Dallas.

Perino, Gregory, and W. J. Bennett, Jr.

1978 Archaeological Investigations at the Mahaffey Site, CH-1, Hugo Reservoir, Choctaw County, Oklahoma. Museum of the Red River, Idabel.
Perttula, Timothy K.

2008 Archeological Investigations in the Late Caddo Village Area of the Roitsch Site. In The Archeology of the Roitsch Site (41RR16), and Early to Historic Period Village on the Red River in Northeast Texas, edited by Timothy K. Perttula, pp. 342-362. Special Publication No. 5. Texas Archeological Society, San Antonio.

2015 The L. L. Winterbauer Site (41WD6), Wood County, Texas. Journal of Northeast Texas Archaeology 53:23-35.

Todd, Jesse

2013 Preliminary Comments on Dog Interments from Archeological Sites in Northeast Texas: Folklore and Archeology. Caddo Archeology Journal 23:85-92.

Schwartz, Marion

2000 The Form and Meaning of Maya and Mississippian Dog Representations. In Dogs Through Time: An Archaeological Perspective, edited by Susan J. Crockford, pp. 217-226. British Archaeological Reports International Series, Volume 889. Archaeopress, Oxford.

Swanton, John R.

1942 Source Material on the History and Ethnology of the Caddo Indians. Bulletin 132. Bureau of American Ethnology, Smithsonian Institution, Washington D.C.

Walker, Danny N.

2000 Preliminary Bibliography on Dogs and Wolves, Stressing their Prehistoric and Historic Occurrence, Hybridisation, and Domestication. In Dogs Through Time: An Archaeological Perspective, edited by Susan J. Crockford, pp. 313-343. British Archaeological Reports International Series, Volume 889. Archaeopress, Oxford. 